\title{
Development of the Child Neglect and Abuse Awareness Scale for Parents and its Relationship with Various Variables
}

\author{
Hazal Begüm Ünal,a, Menekşe Boz ${ }^{\text {b }}$
}

\author{
Received \\ Revised \\ Accepted \\ DOI \\ 10 March 2020 \\ 18 August 2020 \\ 24 August 2020 \\ $10.26822 /$ iejee. 2020.170 \\ "Corresponding Author: Hazal Begüm Ünal. \\ Department of Preschool Education, Faculty of \\ Education, Hacettepe University, Ankara, Turkey. \\ E-mail: begumunal@hacettepe.edu.tr \\ ORCID: http://orcid.org/0000-0002-5053-0515
}

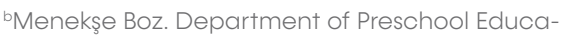
tion, Faculty of Education, Hacettepe University, Ankara, Turkey.

E-mail: mbozster@gmail.com

ORCID: http://orcid.org/0000-0002-6218-105X

\begin{abstract}
This study aims to develop the Child Neglect and Abuse Awareness Scale for Parents (CNAASP) as well as examine their awareness of the children who attend preschools according to age, gender, educational status, and income status. First, the validity and reliability studies were conducted with 595 parents through the random sampling method. Then, the validity and reliability of the study were completed by using CNAASP to determine whether there was a difference in parental awareness according to the variables of gender, age, education, and income. In this study carried out with 144 parents determined by convenience sampling method, t-test and Analysis of Variance (ANOVA) were used in the analysis according to gender variable; Scheffe Test was performed to determine the source of the differences. It was found that there was a significant difference in the mothers' awareness of child neglect and abuse. As a result of the analysis of the income status of the parents, a difference was found in favor of the parents with high-income status in the emotional abuse subscale. As a result of the analysis of the educational status variable of the parents, it was concluded that there was no statistically significant difference.
\end{abstract}

\section{Keywords:}

Child Abuse, Child Neglect, Parent Awareness,

Scale Development, CNAASP

\section{Introduction}

s development continues, children encounter difficulties Athat prepare them for life. These include physical skills such as crawling, walking, running, speaking, and writing, as well as many social experiences such as trust, making friends, and building a positive sense of self. There must be reliable adults around the children who will support them in this journey and guide them for healthy development. However, children who lack this support also lack this guidance (Crasson-Tower, 2005).

Bronfenbrenner (1979) highlighted the components of the ecological environment, such as the interaction of 
the individual, family, society, and sociocultural environments, and stated that each of these components is involved with and affects one another. The relationship such as home, school or work of the individual is defined as microsystem. The relationship between microsystems defined as mesosystem. The exosystem is described units which has no direct relationship with the individual but affects the development of the individual indirectly. Macrosystem is defined as the cultural and belief units of society. Changes that occur over time and affect the development of the individual are defined as chronosystems (Bronfenbrenner, 1989). In the microsystem, which is a layer of the ecological system approach, the interaction of the child with their parents is important. Parents play an important role in the development of the child and have a great responsibility to protect them from many adversities.

Child neglect and abuse, which are defined as all kinds of maltreatment towards the child, are a universal problem (Gilbert et al., 2009). Killing, crippling, and abandoning the newborn and other forms of violence date back to ancient times. History is full of children who have been raised by the family without sufficient care and nutrition or who have been sexually abused (Polat, 2007). Thus, groups and associations have been established to protect the child's interests and to provide protection. Unfortunately, child abuse was not considered as an important global issue until 1962. Child neglect and abuse were first mentioned by Kempe (1962) in the literature as the "Battered child syndrome." Kempe highlighted the clinical manifestations of physical abuse of the child. Over the years, the number of studies has increased, and child neglect and abuse have become the focus of various disciplines (WHO, 2002).

The studies that started in 1962 continued in the 1970 s with studies based on the parent-child relationship. Then, child neglect and abuse began to be seen as a phenomenon originating from multiple reasons family, environment, culture, mental disorders, and so on (Polat, 2007). Children receive their first education in the family. For this reason, the family plays a major role in the development of a child with a healthy personality, self-esteem, and self-confidence; it provides proper support for the physical, cognitive, and social-emotional development of the child into a beneficial individual for the society. Parents play a vital role in the development and education of their children. The child's interactions with the parents, the parents' own attitudes and parents' exposure to abuse in their childhood, as well as resorting to violence to solve a problem and so on, point to the fact that family is one of the biggest risk factors for child neglect and abuse at the microsystem level (General Information about Child Neglect and Abuse, 2018; Polat, 2007; Crosson-Tower, 2005). Parents' disciplinary methods and attitudes used in raising their children sometimes overlap with abuse behaviors (Akduman et al., 2005). Therefore, the parents need to know what child neglect and abuse behaviors are in order to protect their children and know how to behave when faced with such a situation.

Child neglect and abuse occur mainly in 4 ways. These are physical abuse, emotional abuse, sexual abuse, and neglect (Polat, 2007). Physical abuse is deliberate behavior that causes or can cause physical damage to a child's healthy life and development; it is the most common and most easily identified type of abuse (WHO, 1999). Topçu (2009) stated that children who are exposed to physical abuse have more aggressive behaviors; they approach their peers and adults with less empathy than children who have not experienced abuse. Emotional abuse, which is also a very common form of abuse, is a serious disorder pattern in the provision of favorable and supportive environmental conditions for the child's development by the parent or caregiver (WHO, 1999). Anxiety and unrealistic fears, sleep problems and nightmares, biting, kicking, finger sucking, substance use, attention deficit, and sudden decline in success are symptoms of emotional abuse (Gilgun, 2003). A child being sexually coerced, forced into prostitution, and used as a sexual object in crimes such as pornography is defined as sexual abuse (WHO, 1999). Children exposed to sexual abuse face psychosocial and physical problems both in childhood and adulthood. Sleep disorders, a decline in academic achievement, loneliness, insecurity, fear of sexuality or excessive sexuality, anorexia neurosis, bulimia neurosis, overeating, obsessive-compulsive disorder, alcohol and substance dependence, depression, suicidal tendency are observed (Göbekçin, 2013; Akbaş \& Sanberk, 2011). Child neglect is defined as a pattern of inadequacy in providing a child's needs in different areas such as health, education, nutrition, housing, emotional development (WHO, 1999). Physical, emotional, and cognitive disorders are observed in neglected children (Yalçıntaş-Sezgin, 2018). While symptoms such as depression and regression are observed in childhood, during adolescence, they tend to display risky behaviors such as violence, alcohol and substance use, and being dragged into crime. In adulthood, attachment problems, inappropriate problem-solving behaviors, and psychiatric problems are observed (as cited in Yalçıntaş-Sezgin, 2018). Salzinger et al. (1991) found that not only the children who were exposed to abuse but also the children who were exposed to violence and conflicts in the family exhibited aggressive behaviors and that the children raised in these families were inadequate in their ability to solve problems and adapt. 
One out of every ten girls in the world is forced to have sexual intercourse or sexual contact, and one out of three girls who married between the ages of 15-19 is subject to physical, emotional, and sexual violence of their spouses (UNICEF, 2015). Three out of ten adults worldwide believe that physical punishment is the most appropriate way to discipline children (UNICEF, 2015). Approximately 126 million girls aged 15-19 say that husbands have the right to beat their wives in certain situations (UNICEF, 2015). In Turkey, 43\% of the children aged between 7-18 years in the last year were exposed to physical abuse, while 51\%, 3\%, and $25 \%$ of the children were subject to emotional abuse, sexual abuse, and neglect, respectively (UNICEF, 2010). For this reason, researchers from different disciplines conducted studies on the subject and brought different perspectives to the field. Efforts to identify as well as prevent neglect and abuse have increased. Today, in order to protect the interests of children, lawyers, doctors, nurses, law enforcement forces, social service staff, psychologists, sociologists, child development specialists, and guidance as well as psychological counselors work together and have interdisciplinary cooperation.

Many studies maintain that the negative effects of abuse on children continue not only at the time they experience abuse but throughout their lives (Banyard \& Williams, 2007; Fassler et al., 2005; Griffin \& Amodeo, 2010; Bulut, 2007; Bulut, 2008; Pelendecioğlu \& Bulut, 2009). Abused children may experience emotional stress-related psychological symptoms such as fear, anxiety, nightmares, phobias, depression, guilt, low self-esteem, anger and hostility, eating disorders and substance abuse, anti-social behaviors, sexual incompatibility, low sympathy and empathy skills, attachment problems, suicidal behavior, periods of amnesia, physical symptoms, somatoform symptoms, and reactions associated with dissociative identity disorder in some cases (Ovayolu et al., 2007). Therefore, to protect their children from abuse, parents need to know what abuse is, its symptoms, and its effects on their children (Adall, 2007). First of all, it must be determined how aware parents are of what abuse is and how they define it, and families should be guided accordingly. In order to eliminate abuse, it is important to identify families' awareness levels of neglect and abuse. However, to make this identification, a comprehensive, valid, and reliable measurement tool is needed. With the help of a measurement tool, the awareness levels of families about child neglect and abuse, about what should be done to prevent this abuse, what the duties and responsibilities of the related institutions are can easily be determined and, in this way, the development of intervention programs and the planning of training sessions can be facilitated.
This study aims to develop an awareness scale for parents about child neglect and abuse. Children are neglected and abused mostly by their immediate environment. For this reason, the family is particularly important in preventing and identifying abuse (Özer, 2014). When the studies aimed at determining awareness about child neglect and abuse are reviewed in detail, it is seen that although not enough, there are awareness scales especially catered to the occupational groups that play an important role in determining child neglect and abuse such as doctors (Demir, 2013), dentists (Kural-Dıraz, 2014), nurses (Uncu, 2013), social service staff (Osan, 2009), police officers (Sarı, 2010), teachers (Sarıbaş, 2013) and other staff of the school (Akgül, 2015). However, as it is known, families have a very important place in determining child neglect and abuse. Due to the lack of an awareness scale for parents, their awareness levels cannot be determined and thus, counseling and guidance studies for parents cannot be conducted. Therefore, in this study, it is thought that developing a scale that determines child neglect and abuse awareness of parents, examining this awareness in terms of variables, identifying the deficiencies of parents, and organizing education programs and supporting studies to increase the awareness of the parents will contribute to the field. The study aims to develop a child neglect and abuse awareness scale for parents and to examine the awareness of parents of early childhood children according to gender, age, educational level, and income status. Many studies have found relationships between child neglect and abuse and variables such as gender, age, educational status, income status (Uslu et al., 2010; Sari, 2010; Kappa \& Chan, 2011); in some studies, it was found out that these characteristics of the parents posed a risk (Polat, 2007; Crosson-Tower, 2005). In this study, it was investigated whether there was a statistically significant difference between the parents' gender, age, educational status, and income status.

\section{Method}

This descriptive study was conducted in two stages. In the first stage, a scale was developed to measure the awareness of parents about child neglect and abuse. In the second stage, the scores of parents of early childhood children according to various variables were examined.

\section{Participants}

In the scale development phase of the study, the study group consists of 595 children (3-6 years old) who attend preschool education institutions affiliated to the Ministry of National Education (MoNE) in the central districts of Ankara province in the 2016-2017 academic year. The stratified sampling method 


\section{iejee $\approx$}

was used in the scale development stage. Stratified sampling is a sampling method that enables the subgroups in the universe to be identified and represented in the sample by their proportions in the universe (Büyüköztürk, 2014).

Ankara was accepted as the population and the central districts with the highest population density were determined as strata. Based on the distribution of preschool children attending schools affiliated to MoNE, districts were collected at the same ratio from all districts. The study was conducted with 595 parents due to the lack of empty or incomplete answers on the returning forms, even though 712 parents had initially agreed to participate in the study.

Table 1. The Stratify Rates of the Sample of Validity and Reliability Study

\begin{tabular}{lrrr}
\hline District & $\begin{array}{r}\text { Number of } \\
\text { Participants }\end{array}$ & $\begin{array}{r}\text { Number of } \\
\text { Expected } \\
\text { Participants }\end{array}$ & $\begin{array}{r}\text { Percentage } \\
\text { (\%) }\end{array}$ \\
\hline Çankaya & 126 & 126 & 21 \\
\hline Yenimahalle & 96 & 96 & 16 \\
\hline Etimesgut & 86 & 86 & 14.4 \\
\hline Sincan & 65 & 65 & 10.8 \\
\hline Keçiören & 117 & 122 & 20.3 \\
\hline Mamak & 65 & 65 & 10.8 \\
\hline Altındağ & 40 & 40 & 6.7 \\
\hline Total & 595 & 600 & 100 \\
\hline
\end{tabular}

Table 2. Demographic Information of the Samples of Validity and Reliability Study

\begin{tabular}{|c|c|c|c|}
\hline & Groups & $\begin{array}{r}\text { Frequency } \\
\text { (n) }\end{array}$ & $\begin{array}{r}\text { Percentage } \\
(\%)\end{array}$ \\
\hline \multirow{3}{*}{ Gender } & Mother & 484 & 81.3 \\
\hline & Father & 111 & 18.7 \\
\hline & Total & 595 & 100.0 \\
\hline \multirow{6}{*}{ Age } & $20-25$ & 23 & 3.9 \\
\hline & $26-30$ & 123 & 20.7 \\
\hline & $31-35$ & 248 & 41.7 \\
\hline & $36-40$ & 144 & 24.2 \\
\hline & 40 and over & 57 & 9.6 \\
\hline & Total & 595 & 100.0 \\
\hline \multirow{5}{*}{$\begin{array}{l}\text { Level of } \\
\text { Education }\end{array}$} & Middle School or under & 42 & 7.1 \\
\hline & High school graduate & 152 & 25.5 \\
\hline & Collage Graduate & 313 & 52.6 \\
\hline & Postgraduate & 88 & 14.8 \\
\hline & Total & 595 & 100.0 \\
\hline \multirow{6}{*}{$\begin{array}{l}\text { Income } \\
\text { Level }\end{array}$} & $0-2.000$ TRY & 92 & 15.5 \\
\hline & 2.000 TRY - 4.000 TRY & 191 & 32.1 \\
\hline & 4.000 TRY - 6.000 TRY & 146 & 24.5 \\
\hline & 6.000 TRY - 8.000 TRY & 84 & 14.1 \\
\hline & 8.000 TRY and more & 82 & 13.8 \\
\hline & Total & 595 & 100.0 \\
\hline
\end{tabular}

In the second stage of the research, after the validity and reliability study, 350 mothers and fathers of children attending preschool education institutions in Çankaya and Altındağ districts of Ankara province in the 2016-2017 academic year were reached using the convenience sampling method. However, 144 data were collected. Convenience sampling is a method aimed at preventing loss of time, money, and effort (Büyüköztürk, 2014). The forms were sent to the families in envelopes and re-collected with closed envelopes.

Table 3. Demographic Information of the Samples of the Second Phase of the Research

\begin{tabular}{|c|c|c|c|}
\hline & Groups & $\begin{array}{r}\text { Frequency } \\
(n)\end{array}$ & $\begin{array}{r}\text { Percentage } \\
(\%)\end{array}$ \\
\hline \multirow{3}{*}{ Gender } & Mother & 98 & 68.1 \\
\hline & Father & 46 & 31.9 \\
\hline & Total & 144 & 100.0 \\
\hline \multirow{6}{*}{ Age } & $20-25$ & 9 & 6.3 \\
\hline & $26-30$ & 28 & 19.4 \\
\hline & $31-35$ & 34 & 23.6 \\
\hline & $36-40$ & 59 & 41.0 \\
\hline & 40 and over & 14 & 9.7 \\
\hline & Total & 144 & 100.0 \\
\hline \multirow{5}{*}{$\begin{array}{l}\text { Level of } \\
\text { Education }\end{array}$} & Middle School or under & 17 & 11.8 \\
\hline & High school graduate & 42 & 29.2 \\
\hline & Collage Graduate & 73 & 50.7 \\
\hline & Postgraduate & 12 & 8.3 \\
\hline & Total & 144 & 100.0 \\
\hline \multirow{6}{*}{$\begin{array}{l}\text { Income } \\
\text { Level }\end{array}$} & $0-2.000$ TRY & 21 & 14.6 \\
\hline & 2.000 TRY - 4.000 TRY & 45 & 31.3 \\
\hline & 4.000 TRY - 6.000 TRY & 35 & 24.3 \\
\hline & 6.000 TRY - 8.000 TRY & 23 & 16.0 \\
\hline & 8.000 TRY and more & 20 & 13.9 \\
\hline & Total & 144 & 100.0 \\
\hline
\end{tabular}

\section{Data Collection Tool}

For data collection, an information form including personal information about the parents was prepared. The other data collection tool, Child Neglect and Abuse Awareness Scale for Parents (CNAASP), was developed by the researcher. There were 31 scale items written as inverse items, which formed in such a way that they were reversed and scored. The scale consists of a 5-point Likert type (1-strongly disagree, 2-disagree, 3-undecided, 4-agree, 5-strongly agree) and includes 45 items. The scale has 5 sub-dimensions namely General Information Sub-Dimension (12 items), Physical Abuse Sub-Dimension (6 items), Emotional Abuse Sub-Dimension (15 items), Sexual Abuse SubDimension (8 items), Neglect Sub-Dimension (4 items). The high total score determined from adding all the sub-dimensions shows that the awareness of child neglect and abuse is high. As the scale is not 
standardized, scores are evaluated between 1 and 5 . Since this range has a width of 4 points, this width is calculated by dividing it into 5 equal widths.

Table 4. Participation Level Range and Interpretations

\begin{tabular}{lll}
\hline Participation Level & Range & Interpretation \\
\hline 1 & $1.00-1.79$ & Very Low \\
\hline 2 & $1.80-2.59$ & Low \\
\hline 3 & $2.60-3.39$ & Medium \\
\hline 4 & $3.40-4.19$ & High \\
\hline 5 & $4.20-5.00$ & Very High \\
\hline
\end{tabular}

\section{Data Collection Process}

Necessary ethical permissions were obtained from the Hacettepe University Ethics Commission and the MoNE. The parents who were willing to participate in the study were sent the forms in a sealed envelope with the help of the teachers, and the forms that were returned a week later were collected. In order to determine the invariance of the scale over time, forms were re-sent to 24 volunteer parents for testretest analysis at 2-week intervals and analyzed with the data returned. After completing the validity and reliability study of the scale, necessary analyses were performed on the forms sent to the volunteer parents to examine their awareness of child neglect and abuse according to some variables for the other stage of the research.

\section{Data Analysis}

In the first stage of the data analysis, construct validity was tested through item analysis, item-total correlation, and exploratory factor analysis (EFA); for content validity, the Content Validity Ratio (CVR) and Content Validity Index (CVI) were used. The reliability was determined by the re-test and internal consistency coefficient. EFA is used to determine whether the underlying factor of the data is sufficient for a hypothesis and to determine the number of factors. Confirmatory factor analysis (CFA) is a model that tests theory rather than a model that produces theory (Doğan et al., 2017). While EFA is used for scale development and structure validation, CFA is used when building the structure with previous experimental and theoretical foundations (Brown, 2006).

In the study, independent samples t-test and one-way analysis of variance (ANOVA) were used to determine the relationship between the parental awareness of neglect and abuse with various variables, and the Scheffe test was used to find the source of the differences. In the analysis, the level of significance was accepted as .05.

\section{Results}

In this section, first, the findings of the scale development, and then, the findings of whether there is a significant difference in the mean scores of parental awareness obtained from CNAASP depending on some variables are presented.

\section{Validity}

During the development of the measurement tool, the literature was reviewed and an item pool was created. While constructing the items, it was taken into account that they did not contain factual expressions; thus, a simple language was used and the items did not contain more than one judgment and two negative expressions (Tezbaşaran, 1996). For content validity, changes were made by consulting a language expert and an assessment and evaluation expert, and then, the opinions of one social service specialist, one psychologist, two guidance and psychological counseling specialists, and five preschool education experts were obtained.

Since number of the experts was 9, minimum value of the CRV was accepted as .75 based on the criteria determined by Veneziano and Hooper (1997). The $\mathrm{CVI}$ was then calculated for all items and it was found to be .92. The scale validity was found to be statistically significant as CVI> CVR. Afterward, during the pilot study, the scale was applied to 20 parents whose children were attending pre-schools, and the comprehensibility of the items was confirmed. The final version of the scale included 60 items.

As a result of Bartlett's test ( $p=.000<.05)$, it was found that there was a relationship between the variables included in factor analysis, and with the Kaiser-MeyerOlkin $(\mathrm{KMO})$ calculation $(\mathrm{KMO}=.82>.60)$, the sample size was found to be sufficient for factor analysis. The KMO value for each sub-dimension was found to be quite high considering the acceptable limit of .50 (Field, 2013). As a result, the factor loadings of the five factors formed as a result of the factor analysis on the scale varied between .51 and .90. The EFA, which helps to make sense of the items as a whole and to gather the items that serve the same purpose together, is performed for the construct validity of the scale. If there is a cluster of items that has a high level of relationship with a factor, it means that those items measure a concept together (Büyüköztürk, 2002).

In factor analysis, the varimax method was chosen and, in this way, the structure of the relationship between the factors remained the same. Rennie (1997) suggests that the researcher should use the vertical rotation method if they are interested in the 
generalizability of the results. It is also recommended the use of vertical rotation as the vertical rotation and oblique rotation results do not make a significant difference between each other and facilitate the interpretation of the vertical rotation results. Although there are 3 types of vertical rotation, the varimax method is recommended because it distinguishes the factors more clearly (SSencan, 2005).

As a result of the factor analysis, it was seen that the variables grouped under 5 factors, which explained $43.04 \%$ of the total variance. Considering the items in the scale, the factors were defined as General information (e.g., "Although child abuse and neglect should not be experienced at all, the child may not be right all the time"), Physical Abuse (e.g., "Under no circumstances children should be exposed to violence"), Emotional Abuse (e.g., "Children learn better to behave correctly when they are compared to their peers"), Sexual Abuse (e.g., "The rate of exposure to sexual abuse varies according to the gender of children"), and Neglect (e.g., "Even if they are younger than 12 years of age, children can stay alone in their own homes if necessary").

The factor loadings of the General Information SubScale (12 items) ranged between .55 and .62, while the factor loadings of the Physical Abuse Sub-Scale (6 items) ranged from .50 to .80. The factor loadings of Emotional Abuse Sub-Scale (15 items), the Sexual Abuse Sub-Scale (8 items), and the Neglect Sub-Scale (4 items) ranged from .55 to .81, .59 to .67, and .82 to .89 , respectively (Table 5). Büyüköztürk (2007) argued that the factor loadings of 0.45 or higher would be a good measure. It is accepted that it is sufficient if the variance explained in the scale development studies conducted in social sciences is between 40-60\% (Tavşancll, 2014). Bartlett Sphericity test results of factor analysis showed that $p=.00(p<.05)$, which meant that the data was suitable for factor analysis (Pett et al., 2003).

\section{Reliability}

For the reliability of the scale, total item correlation, Cronbach's alpha internal consistency coefficient, and the test-retest reliability coefficient were calculated. Total item correlation shows the internal consistency reliability of the scale as a result of the calculation of the correlation between the total scores of the scale and the scores for each item.
Table 5. Factor Loadings of CNAASP

\begin{tabular}{|c|c|c|c|c|c|}
\hline Items & $\begin{array}{l}\text { General } \\
\text { Information }\end{array}$ & $\begin{array}{l}\text { Physical } \\
\text { Abuse }\end{array}$ & $\begin{array}{l}\text { Emotional } \\
\text { Abuse }\end{array}$ & $\begin{array}{l}\text { Sexual } \\
\text { Abuse }\end{array}$ & Neglect \\
\hline M3 & .62 & & & & \\
\hline M8 & .58 & & & & \\
\hline M9 & .57 & & & & \\
\hline M10 & .57 & & & & \\
\hline M27 & .56 & & & & \\
\hline M28 & .62 & & & & \\
\hline M32 & .63 & & & & \\
\hline M39 & .59 & & & & \\
\hline M46 & .55 & & & & \\
\hline M48 & .59 & & & & \\
\hline M54 & .56 & & & & \\
\hline M56 & .55 & & & & \\
\hline M19 & & .80 & & & \\
\hline M23 & & .79 & & & \\
\hline M30 & & .77 & & & \\
\hline M41 & & .60 & & & \\
\hline M49 & & .66 & & & \\
\hline M55 & & .50 & & & \\
\hline M15 & & & .81 & & \\
\hline M2O & & & .79 & & \\
\hline M24 & & & .73 & & \\
\hline M29 & & & .70 & & \\
\hline M31 & & & .69 & & \\
\hline M33 & & & .60 & & \\
\hline M35 & & & .60 & & \\
\hline M36 & & & .58 & & \\
\hline M37 & & & .55 & & \\
\hline M40 & & & .55 & & \\
\hline M43 & & & .57 & & \\
\hline M44 & & & .61 & & \\
\hline M50 & & & .55 & & \\
\hline M53 & & & .55 & & \\
\hline M59 & & & .59 & & \\
\hline M11 & & & & .67 & \\
\hline M13 & & & & .66 & \\
\hline M18 & & & & .65 & \\
\hline M21 & & & & .62 & \\
\hline M23 & & & & .66 & \\
\hline M45 & & & & .61 & \\
\hline M51 & & & & .60 & \\
\hline M57 & & & & .59 & \\
\hline M22 & & & & & .89 \\
\hline M26 & & & & & .89 \\
\hline M42 & & & & & .86 \\
\hline M52 & & & & & .82 \\
\hline
\end{tabular}


Table 6. Total Item Correlation

\begin{tabular}{|c|c|c|c|c|c|}
\hline & $\begin{array}{l}\text { General } \\
\text { Information }\end{array}$ & $\begin{array}{l}\text { Physical } \\
\text { Abuse }\end{array}$ & $\begin{array}{l}\text { Emotional } \\
\text { Abuse }\end{array}$ & $\begin{array}{l}\text { Sexual } \\
\text { Abuse }\end{array}$ & Neglect \\
\hline Items & Total Item & Correlation & & & \\
\hline M3 & .70 & & & & \\
\hline M8 & .59 & & & & \\
\hline M9 & .76 & & & & \\
\hline M10 & .79 & & & & \\
\hline M27 & .79 & & & & \\
\hline M28 & .55 & & & & \\
\hline M32 & .61 & & & & \\
\hline M39 & .59 & & & & \\
\hline M46 & .77 & & & & \\
\hline M48 & .72 & & & & \\
\hline M54 & .58 & & & & \\
\hline M56 & .58 & & & & \\
\hline M19 & & .95 & & & \\
\hline M23 & & .96 & & & \\
\hline M30 & & .88 & & & \\
\hline M41 & & .89 & & & \\
\hline M49 & & .72 & & & \\
\hline M55 & & .79 & & & \\
\hline M15 & & & .53 & & \\
\hline M2O & & & .51 & & \\
\hline M24 & & & .52 & & \\
\hline M29 & & & .79 & & \\
\hline M31 & & & .52 & & \\
\hline M33 & & & .99 & & \\
\hline M35 & & & .97 & & \\
\hline M36 & & & .93 & & \\
\hline M37 & & & .95 & & \\
\hline M40 & & & .89 & & \\
\hline M43 & & & .78 & & \\
\hline M44 & & & .84 & & \\
\hline M50 & & & .84 & & \\
\hline M53 & & & .81 & & \\
\hline M59 & & & .88 & & \\
\hline M11 & & & & .67 & \\
\hline M13 & & & & .77 & \\
\hline M18 & & & & .79 & \\
\hline M21 & & & & .66 & \\
\hline M23 & & & & .55 & \\
\hline M45 & & & & .61 & \\
\hline M51 & & & & .80 & \\
\hline M57 & & & & .57 & \\
\hline M22 & & & & & .56 \\
\hline M26 & & & & & .59 \\
\hline M42 & & & & & .61 \\
\hline M52 & & & & & .59 \\
\hline
\end{tabular}

Büyüköztürk (2007) states that items with a total correlation of .30 and higher can accurately differentiate between individuals, whereas Tavşancll (2014) argues that when this limit is higher than .40, more accurate results are reached. In this context, it was decided that the total item correlation value would be .50 and above because high total item correlation is a sign of better distinguishing the items of the scale, and the scale provides a more robust structure upon request; thus, 15 items were excluded from the scale as their correlation value was lower than .50. As a result, 45 items were included in the final version of the scale. The EFA of the scale was conducted on those 45 items.

As a result of item analysis, it was seen that when the total item correlation value and item factor loadings are considered, the values were compatible with the values in the literature (Tables 5 and 6), meaning that the scale is valid.

For the test-retest reliability study of the scale, 24 parents were identified after the first application and the second application, which was performed 2 weeks later. The time between the two applications should be short enough not to change the measured characteristics of the individuals and long enough not to affect the scores (Büyüköztürk et al., 2009). The Pearson Product Moment Correlation Coefficient was calculated for the obtained data. The test-retest correlation coefficient of the scale was calculated as 0.80, which was expected to be at least .70 (Tavşancll, 2014). As it was .80, the scale was found to be invariant to time.

Table 7. Internal Consistency Reliability Coefficients of CNAASP

\begin{tabular}{lr}
\hline & Internal Consistency \\
\hline General Information & .66 \\
\hline Physical Abuse & .80 \\
\hline Emotional Abuse & .86 \\
\hline Sexual Abuse & .80 \\
\hline Neglect & .90 \\
\hline CNAASP & .80 \\
\hline
\end{tabular}

According to the table, the internal consistency coefficient (Cronbach Alpha) of the 45-item CNAASP was found to be 80 . The internal consistency coefficients of the sub-dimensions were found to be .66 for the General Information subscale, .80 for the Physical Abuse sub-dimension, .86 for the Emotional Abuse sub-dimension, .80 for the Sexual Abuse subdimension, and .90 for the Neglect sub-dimension ( $p<$ .01). As a result of both analyses, reliability coefficients show that the scale is reliable. 
Following the findings of the scale development, in the second stage of the study, the findings as to whether the mean scores obtained by the parents of early childhood children ages between 3-6 $(n=144)$ from the scale are affected by some variables are given.

Child neglect and abuse awareness scores of the parents of children in the early childhood period showed statistically significant differences according to their parental status $\left(t_{(144)}=-2.1 ; p=.03<.05\right)$. The mothers' awareness scores were higher than those of the fathers (Table 8).

The findings as to whether the parents' neglect and abuse awareness scores show a significant difference according to their income level are given below.

The mean emotional abuse awareness scores of the parents who participated in the study were found to be significant according to the family income level $(F=2.7 ; p=.03<.05)$. In order to determine the sources of the differences, the Scheffe Test, one of the complementary post hoc analyses, was performed. The emotional abuse awareness scores of parents with an income level of 6.000 TRY - 8.000 TRY (2.62 \pm .36) were found to be higher than that of parents with an income level of $0-2.000$ TRY $(2.3 \pm .36)$. The emotional abuse awareness scores $(2.62 \pm .33)$ of those with a family income of TRY 8.000 or more were higher than that of those with a family income of TRY $0-2.000(2.32 \pm .36)$. (Table 9)

The findings as to whether parental awareness of child neglect and abuse differ significantly according to the age of the parents are given below.

The awareness levels of the parents in the study showed a statistically significant difference according to age $(F=3.4 ; p=.010<.05)$. According to the Scheffe Test conducted to determine the sources of the differences, child abuse and neglect awareness level of those aged 36-40 were found to be higher than those aged 26-30. Also, when the sub-dimensions are examined, it is seen that their awareness of emotional abuse and neglect shows a significant difference according to the age variable. It is observed that the emotional abuse awareness level of those aged 20-25 years is higher than other age groups, but as far as the neglect sub-dimension is concerned, those aged 40 and over have a higher level of neglect awareness. (Table 10)

The study revealed no statistically significant difference between parents' education level and child abuse and neglect awareness. (Table 11)

\section{Discussion}

Büyüköztürk (2007) maintains that the factor loadings of .45 or higher would be a good measure. Following the total item correlation calculations, it was seen that the factor loadings of the remaining items varied between .50 and .90. As a result of the item analysis, considering the total item correlation and item factor loadings, it was concluded that the scale developed within the scope of the study was valid because the values were in line with the values in the literature.

According to Kalayci's (2010) Cronbach's Alpha Coefficient value interpretation, the reliability coefficients of the subscales were calculated as .65 (General Information Sub-Scale; fairly reliable), .80 (Physical Abuse Sub-Scale; fairly reliable), .85 (Emotional Abuse Sub-Scale; highly reliable), .80 (Sexual Abuse Sub-Scale; fairly reliable), and .90 (Neglect Sub-Scale; highly reliable). The Cronbach's Alpha reliability coefficient of the 45-item CNAASP was found to be .81, meaning that the scale overall is highly reliable.

When the differences in the awareness scores of the parents were taken into consideration based on gender, it was found that the awareness scores of the mothers were higher than those of the fathers, meaning that there was a significant difference in favor of the mothers. This may be explained by the fact that mothers play a primary role in child care. Studies have argued that healthy mother-child

Table 8. $t$-Test Results for CNAASP Scores by Gender

\begin{tabular}{|c|c|c|c|c|c|c|}
\hline & & $n$ & $M$ & sd & $t$ & $p$ \\
\hline \multirow{2}{*}{ CNAASP } & Mother & 98 & 2.82 & .22 & \multirow{2}{*}{-2.13} & \multirow{2}{*}{.03} \\
\hline & Father & 46 & 2.74 & .16 & & \\
\hline \multirow{2}{*}{$\begin{array}{l}\text { General } \\
\text { Information }\end{array}$} & Mother & 98 & 2.60 & .33 & \multirow{2}{*}{-.05} & \multirow{2}{*}{.95} \\
\hline & Father & 46 & 2.61 & .26 & & \\
\hline \multirow{2}{*}{ Physical Abuse } & Mother & 98 & 3.11 & .52 & \multirow{2}{*}{-1.98} & \multirow{2}{*}{.03} \\
\hline & Father & 46 & 2.93 & .43 & & \\
\hline \multirow{2}{*}{ Emotional Abuse } & Mother & 98 & 2.64 & .33 & \multirow{2}{*}{5.95} & \multirow{2}{*}{$.000^{\circ}$} \\
\hline & Father & 46 & 2.29 & .33 & & \\
\hline \multirow{2}{*}{ Sexual Abuse } & Mother & 98 & 2.94 & .39 & \multirow{2}{*}{-2.14} & \multirow{2}{*}{.03} \\
\hline & Father & 46 & 2.79 & .37 & & \\
\hline \multirow{2}{*}{ Neglect } & Mother & 98 & 3.14 & .58 & \multirow{2}{*}{-4.18} & \multirow{2}{*}{.000} \\
\hline & Father & 46 & 2.72 & .48 & & \\
\hline
\end{tabular}

${ }^{*} p<.05$ 
Table 9. One-way ANOVA Test Results for the CNAASP Scores According to Income level

\begin{tabular}{|c|c|c|c|c|c|c|c|}
\hline & & $n$ & M & $s d$ & $F$ & $p$ & Difference \\
\hline \multirow{5}{*}{ CNAASP } & $0-2.000 \mathrm{TRY}$ & 21 & 2.73 & .23 & \multirow{5}{*}{.40} & \multirow{5}{*}{.80} & \\
\hline & 2.000 TRY - 4.000 TRY & 45 & 2.75 & .19 & & & \\
\hline & 4.000 TRY - 6.000 TRY & 35 & 2.76 & .19 & & & \\
\hline & 6.000 TRY - 8.000 TRY & 23 & 2.80 & .21 & & & \\
\hline & 8.000 TRY and more & 20 & 2.78 & .24 & & & \\
\hline \multirow{5}{*}{ General Information } & $0-2.000$ TRY & 21 & 2.55 & .29 & \multirow{5}{*}{.24} & \multirow{5}{*}{.91} & \\
\hline & 2.000 TRY - 4.000 TRY & 45 & 2.60 & .26 & & & \\
\hline & 4.000 TRY - 6.000 TRY & 35 & 2.61 & .39 & & & \\
\hline & 6.000 TRY - 8.000 TRY & 23 & 2.62 & .29 & & & \\
\hline & 8.000 TRY and more & 20 & 2.64 & .33 & & & \\
\hline \multirow{5}{*}{ Physical Abuse } & $0-2.000$ TRY & 21 & 3.03 & .45 & \multirow{5}{*}{.32} & \multirow{5}{*}{.86} & \\
\hline & 2.000 TRY - 4.000 TRY & 45 & 2.93 & .51 & & & \\
\hline & 4.000 TRY - 6.000 TRY & 35 & 3.05 & .50 & & & \\
\hline & 6.000 TRY - 8.000 TRY & 23 & 2.97 & .47 & & & \\
\hline & 8.000 TRY and more & 20 & 2.99 & .59 & & & \\
\hline \multirow{5}{*}{ Emotional Abuse } & $0-2.000 \mathrm{TRY}$ & 21 & 2.32 & .36 & \multirow{5}{*}{2.74} & \multirow{5}{*}{$.03^{*}$} & \multirow{5}{*}{$\begin{array}{l}4>1 \\
5>1\end{array}$} \\
\hline & 2.000 TRY - 4.000 TRY & 45 & 2.50 & .38 & & & \\
\hline & 4.000 TRY - $6.000 \mathrm{TRY}$ & 35 & 2.59 & .34 & & & \\
\hline & 6.000 TRY - 8.000 TRY & 23 & 2.62 & .36 & & & \\
\hline & 8.000 TRY and more & 20 & 2.62 & .33 & & & \\
\hline \multirow{5}{*}{ Sexual Abuse } & $0-2.000$ TRY & 21 & 2.85 & .36 & \multirow{5}{*}{.38} & \multirow{5}{*}{.82} & \\
\hline & 2.000 TRY - 4.000 TRY & 45 & 2.85 & .41 & & & \\
\hline & 4.000 TRY - 6.000 TRY & 35 & 2.80 & .40 & & & \\
\hline & 6.000 TRY - 8.000 TRY & 23 & 2.90 & .34 & & & \\
\hline & 8.000 TRY and more & 20 & 2.76 & .42 & & & \\
\hline \multirow{5}{*}{ Neglect } & $0-2.000 \mathrm{TRY}$ & 21 & 2.91 & .58 & \multirow{5}{*}{.31} & \multirow{5}{*}{.86} & \\
\hline & 2.000 TRY - 4.000 TRY & 45 & 2.86 & .63 & & & \\
\hline & 4.000 TRY - 6.000 TRY & 35 & 2.76 & .60 & & & \\
\hline & 6.000 TRY - 8.000 TRY & 23 & 2.90 & .57 & & & \\
\hline & 8.000 TRY and more & 20 & 2.88 & .49 & & & \\
\hline
\end{tabular}

${ }^{*} p<.05$

interaction and communication can reduce child neglect and abuse. The importance of mothers in their children's lives was supported by these studies as well. Therefore, the mothers' higher levels of awareness of child neglect and abuse compared to those of the fathers can be attributed to this fact

The study conducted by Sarı (2010) investigated the physical abuse potential of the parents working for the police forces and it was found that the abuse potential was low in this group. In addition, it was concluded that the abuse potential scores of the mothers were lower than the fathers. Based on this, it can be considered that families with low physical abuse potential have a high awareness of physical abuse. The findings of our study are similar to those of Sarı (2010). Furthermore, in their study, Uslu et al. (2010) also found that mothers' emotional abuse awareness was higher than that of fathers. Also, Asla et al. (2011) revealed that the mothers' awareness is higher than that of the fathers when the physical abuse awareness of parents with high potential of abuse is examined. It can be said that these findings are also similar to the findings of our study.
As a result of this study, it was concluded that the awareness scores of the parents with high-income levels and the awareness scores of the parents with low-income levels did not differ. However, when the averages of the scores are examined, it is seen that as income level increases, the mean awareness scores also increase. At the same time, it was observed that in the emotional abuse subscale, there was an increase in the mean awareness scores as the income level increased, and the emotional abuse awareness of the families with an income of 6.000-8.000 TRY and 8.000 TRY and more was found to be higher than those with 0-2.000 TL income level. The reason for this is that as the parents' income level increases, there seems to be more access to information and thus, parents can support their personal development more. The results of our study coincide with those of Uslu et al. (2010), who also stated that families with low income have low awareness of emotional abuse. However, in the study by Cappa and Khan (2011), no statistically significant difference was found when the income levels of the mothers of the children who were and were not exposed to physical abuse were compared. Studies have argued that as the income level of the 
Table 10. One-Way ANOVA Test Results for the CNAASP Level by Age

\begin{tabular}{|c|c|c|c|c|c|c|c|}
\hline & & $n$ & M & $s d$ & $F$ & $p$ & Difference \\
\hline \multirow{5}{*}{ CNAASP } & $20-25$ & 9 & 2.63 & .30 & \multirow{5}{*}{3.4} & \multirow{5}{*}{$.01^{*}$} & \multirow{5}{*}{$4>2$} \\
\hline & $26-30$ & 28 & 2.69 & .24 & & & \\
\hline & $31-35$ & 34 & 2.74 & .19 & & & \\
\hline & $36-40$ & 59 & 2.82 & .18 & & & \\
\hline & 40 and over & 14 & 2.80 & .12 & & & \\
\hline \multirow{5}{*}{ General Information } & $20-25$ & 9 & 2.50 & .38 & \multirow{5}{*}{1.38} & \multirow{5}{*}{.24} & \\
\hline & $26-30$ & 28 & 2.56 & .39 & & & \\
\hline & $31-35$ & 34 & 2.54 & .31 & & & \\
\hline & $36-40$ & 59 & 2.66 & .26 & & & \\
\hline & 40 and over & 14 & 2.66 & .27 & & & \\
\hline \multirow{5}{*}{ Physical Abuse } & $20-25$ & 9 & 2.74 & .68 & \multirow{5}{*}{.73} & \multirow{5}{*}{.56} & \\
\hline & $26-30$ & 28 & 2.95 & .56 & & & \\
\hline & $31-35$ & 34 & 3.02 & .52 & & & \\
\hline & $36-40$ & 59 & 3.02 & .45 & & & \\
\hline & 40 and over & 14 & 3.04 & .38 & & & \\
\hline \multirow{5}{*}{ Emotional Abuse } & $20-25$ & 9 & 2.88 & .44 & \multirow{5}{*}{6.07} & \multirow{5}{*}{$.000^{*}$} & \multirow{5}{*}{$\begin{array}{l}1>5 \\
1>4 \\
2>5\end{array}$} \\
\hline & $26-30$ & 28 & 2.69 & .28 & & & \\
\hline & $31-35$ & 34 & 2.53 & .37 & & & \\
\hline & $36-40$ & 59 & 2.46 & .35 & & & \\
\hline & 40 and over & 14 & 2.28 & .31 & & & \\
\hline \multirow{5}{*}{ Sexual Abuse } & $20-25$ & 9 & 2.75 & .12 & \multirow{5}{*}{1.19} & \multirow{5}{*}{.31} & \\
\hline & $26-30$ & 28 & 2.71 & .49 & & & \\
\hline & $31-35$ & 34 & 2.83 & .40 & & & \\
\hline & $36-40$ & 59 & 2.90 & .37 & & & \\
\hline & 40 and over & 14 & 2.86 & .29 & & & \\
\hline \multirow{5}{*}{ Neglect } & $20-25$ & 9 & 2.27 & .52 & \multirow{5}{*}{8.75} & \multirow{5}{*}{$.000^{*}$} & \multirow{5}{*}{$\begin{array}{l}4>1 \\
5>1 \\
4>2 \\
5>2\end{array}$} \\
\hline & $26-30$ & 28 & 2.55 & .55 & & & \\
\hline & $31-35$ & 34 & 2.76 & .57 & & & \\
\hline & $36-40$ & 59 & 3.06 & .53 & & & \\
\hline & 40 and over & 14 & 3.17 & .30 & & & \\
\hline
\end{tabular}

${ }^{*} p<.05$

family decreases, financial stress increases, which is related to the behavioral problems in children and that such families are more prone to abuse their children (Liu \& Merritt, 2018; Maguire-Jack \& Negash, 2016; Warren \& Font, 2015). Furthermore, Burlaka et al., (2017) concluded that the high-income of the family increases positive parental behavior while reducing the negative behaviors (physical punishment, inconsistent parenting, and poor supervision).

The current study also revealed that the awareness scores of the parents between the ages of 26-30 were lower than that of the parents between the ages of 36-40 and there was a significant difference between them. Given that having a child at an early age increases the potential of child abuse, it is thought that this is the reason for the increase in awareness level as the age increases. However, in the emotional abuse subscale, it was concluded that the emotional abuse awareness scores of the parents between the ages of 20-30 were higher than the others. This means that young parents adopt more democratic parental attitudes than changing parental attitudes and this may be the reason for the difference. The findings of the study are similar to those of Uslu et al.'s (2010) study, which explained that having a child at an early age is one of the reasons for the low awareness of emotional abuse.

Our study also examined whether there was a relationship between the parents' educational status and awareness scores. It was concluded that there was no statistically significant difference. In the Turkish education system, generally, no training is provided on child neglect and abuse, and even if training is given, it is insufficient. Other than families, the teachers spend most of the time with children. However, even in the education faculties of universities, there is no compulsory child neglect and abuse course. The fact that there is no difference in awareness scores based on the educational level can be attributed to the fact that regardless of their educational background, no parents can receive any training for child neglect and abuse. The findings of this study are similar to those of Cappa and Khan (2011), who compared the educational status of mothers of children who were exposed to physical abuse and that of mothers of children who were not exposed to physical abuse, 
Table 11. One-Way ANOVA Test Results for the CNAASP Level by Education

\begin{tabular}{|c|c|c|c|c|c|c|}
\hline & & $n$ & M & sd & $F$ & $p$ \\
\hline \multirow{4}{*}{ CNAASP } & Middle School or under & 17 & 2.73 & .23 & \multirow{4}{*}{.80} & \multirow{4}{*}{.49} \\
\hline & High school graduate & 42 & 2.73 & .21 & & \\
\hline & Collage Graduate & 73 & 2.78 & .20 & & \\
\hline & Postgraduate & 12 & 2.79 & .18 & & \\
\hline \multirow{4}{*}{ General Information } & Middle School or under & 17 & 2.72 & .31 & \multirow{4}{*}{1.30} & \multirow{4}{*}{.27} \\
\hline & High school graduate & 42 & 2.63 & .29 & & \\
\hline & Collage Graduate & 73 & 2.57 & .32 & & \\
\hline & Postgraduate & 12 & 2.53 & .29 & & \\
\hline \multirow{4}{*}{ Physical Abuse } & Middle School or under & 17 & 3.00 & .45 & \multirow{4}{*}{2.40} & \multirow{4}{*}{.07} \\
\hline & High school graduate & 42 & 2.83 & .42 & & \\
\hline & Collage Graduate & 73 & 3.05 & .55 & & \\
\hline & Postgraduate & 12 & 3.18 & .37 & & \\
\hline \multirow{4}{*}{ Emotional Abuse } & Middle School or under & 17 & 2.41 & .30 & \multirow{4}{*}{.81} & \multirow{4}{*}{.48} \\
\hline & High school graduate & 42 & 2.57 & .41 & & \\
\hline & Collage Graduate & 73 & 2.54 & .35 & & \\
\hline & Postgraduate & 12 & 2.48 & .37 & & \\
\hline \multirow{4}{*}{ Sexual Abuse } & Middle School or under & 17 & 2.74 & .46 & \multirow{4}{*}{.49} & \multirow{4}{*}{.68} \\
\hline & High school graduate & 42 & 2.84 & .38 & & \\
\hline & Collage Graduate & 73 & 2.84 & .39 & & \\
\hline & Postgraduate & 12 & 2.91 & .38 & & \\
\hline \multirow{4}{*}{ Neglect } & Middle School or under & 17 & 2.77 & .64 & \multirow{4}{*}{.62} & \multirow{4}{*}{.60} \\
\hline & High school graduate & 42 & 2.77 & .63 & & \\
\hline & Collage Graduate & 73 & 2.92 & .55 & & \\
\hline & Postgraduate & 12 & 2.85 & .51 & & \\
\hline
\end{tabular}

and found no statistically significant difference between the two groups, arguing that being exposed to physical abuse is not related to the mothers' educational level. After the implementation program they employed, Chavis et al. (2013) concluded that there was no change in the attitudes of parents, who received a university education, toward beating as a disciplinary method and the scores obtained from the scale suggest that they are more prone to physical abuse than the parents who have high school or lower education degrees. In another study, Liel et al. (2019) concluded that the higher educational level of parents decreases the potential for child abuse. Also, Miragoli et al. (2015) emphasized that the fathers, who graduated from a university, had less child abuse potential than fathers with a high school or lower education degree. Burlaka et al. (2017) concluded that the higher education status of parents increases positive parental behavior and reduces negative parental behavior (physical punishment, inconsistent parenting, and poor supervision).

\section{Conclusion}

As a result of this study, a scale was developed to measure parental awareness levels about child neglect and abuse. A Likert-type scale form was distributed to the families of children attending preschools, and the validity and reliability studies of the scale were conducted in the light of the collected data. The scale, which was finalized based on expert opinions, was subject to exploratory factor analysis, and the items with equal loadings were removed from the scale. Item analysis and factor analysis were conducted and the items with an item correlation value below 0.50 (a total of 15 items) were removed from the scale.

Bartlett's test $(p=.000<.05)$ revealed that there was a relationship between the variables, and as the calculated KMO value was .824> .60, it was concluded that the sample size was suitable for factor analysis. As a result of factor analysis, the variance explained was found to be $43.04 \%$, and a total of 5 factors emerged. The Cronbach's alpha reliability coefficient of the 45-item scale was calculated as .81. The reliability coefficients of the subscales were calculated as .65 (General Information Sub-Scale), .80 (Physical Abuse Sub-Scale), .85 (Emotional Abuse Sub-Scale), .80 (Sexual Abuse Sub-Scale), and .90 (Neglect SubScale). In light of this information, it was concluded that CNAASP is a valid and reliable scale.

After the validity and reliability tests of the scale, the awareness of the parents was evaluated based on different variables. The general awareness level of the parents was found to be low-medium. It was examined whether there was a difference in the awareness scores of the parents according to gender and it was concluded that the awareness scores of the mothers were higher than those of the fathers. It was also examined whether there was a difference in 


\section{iejee $\approx$}

the awareness scores of the parents according to their income status and it was concluded that the mean awareness scores increased as the family income level increased. Whether the age of the parents made a difference in awareness scores was also investigated, and it was seen that the participants in the 36-40 age group had higher levels of awareness than the participants in the 26-30 age group. Furthermore, it was examined whether there was a difference in the awareness scores of the parents according to their educational level, and no significant difference was found between the groups.

\section{Recommendations}

This research is limited only to the province of Ankara. The second stage of the study is limited to the small sample group since it is studied with the appropriate sampling method. The generalizability of the CNAASP can be done by collecting data a larger sample from different cities of Turkey. As a result of the literature review, it was found that studies on child neglect and abuse awareness towards parents were insufficient. In order to overcome this deficiency, it is strongly recommended to conduct academic studies on parental awareness. Standardization of CNAASP is recommended to determine whether parental awareness is low or high. Once the scale becomes a standard, the parental awareness level can be more clearly determined. In this study, only parents of preschool children were studied. A validity-reliability study would be appropriate for the sample group of parents who have children ages between 0-18. In this study, the variables of age, gender, education, and income status of the parents were examined; however, different variables can be examined in future studies. The differences between the parental awareness of the variables discussed in this study can be examined in more detail with the qualitative research method and the reasons for these differences can be revealed.

\section{Acknowledgements}

We want to thank the parents participating our research. Also, a particular thanks goes to Hacettepe Teknokent Teknoloji Transfer Merkezi for their proofreading services.

References

Adalı, N. (2007). 10-12 yaş grubu çocuk istismarı ebeveyn ve çocuk bilgilendirme çalışması [The information study of child abuse for 1012 age group for parent and children], Tezsiz Yüksek Lisans Programı Dönem Projesi. Ankara University, Institute of Social Sciences.

Akbaş, T. \& Sanberk, i. (2011). Çocuklara yönelik cinsel taciz ve koruyucu eğitim [The education of sexual harassment and protective education]. Seçkin.

Akduman, G. G., Ruban, C., Akduman, B. \& Korkusuz, i. (2005). Çocuk ve cinsel istismar [Child and sexual abuse]. Adli Psikiyatri Dergisi, 3(1), 9-14.
September 2020, Volume 13, Issue 1, 21-34

Akgül, E. (2015). Okul öncesi eğitim kurumlarında çalışan personelin cinsel istismar bildirim durumları [A study about reporting status of child sexual abuse by the staff working in preschool educaiton centers](Master Thesis). Hacettepe University, Institute of Educational Sciences.

Asla, N., Paul, J. \& Perez-Albeniz, A. (2011). Emotional recognition in fathers and mothers at highrisk for child physical abuse. Child Abuse and Neglect, 35, 712-721.

Banyard, V. L., \& Williams, L. M. (2007). Women's voices on recovery: A multi-method study of the complexity of recovery from child sexual abuse. Child Abuse \& Neglect, 31(3), 275-290.

Bronfenbrenner, U. (1979). The ecology of human development. Harvard University Press.

Bronfenbrenner, U. (1989). Ecological systems theory. Annals of Child Development, 6, 185-246.

Bulut, S. (2007). Defining sexual abuse and the following procedure. [Çocuk cinsel istismarı hakkında bir derleme.] Turkish Psychological Counseling and Guidance Journal, 28(3), 139-156.

Bulut, S. (2008). Sexually abused pre-school children's diagnosis and treatment via psychodynamic play therapy. [Erken çocukluk dönemi cinsel istismarının psikodinamik oyun terapisi ile teşhisi ve tedavi edilmesi.] Turkish Psychological Counseling and Guidance Journal, 29(3), 131144.

Burlaka, V., Graham-Bermann, S. A., \& Delva, J. (2017). Family factors and parenting in Ukraine. Child Abuse \& Neglect, 72, 154-162.

Büyüköztürk, S.., Kılıç-Çakmak, E., Akgün, E. Ö., Karadeniz, S. ve Demirel, F. (2014). Bilimsel araştırma yöntemleri [Scientific research methods]. Pegem.

Büyüköztürk, Ş. (2002). Faktör analizi: Temel kavramlar ve ölçek geliştirmede kullanımı [Factor analysis: Basic concepts and using to development scale]. Kuram ve Uygulamada Eğitim Yönetimi, 32(32), 470-483.

Büyüköztürk, Ş. (2007). Sosyal bilimler için veri analizi el kitabı [Manual of data analysis for social sciences]. Pegem.

Büyüköztürk, Ş. (2014). Sosyal bilimler için veri analizi el kitabı [Manual of data analysis for social sciences]. Pegem.

Cappa, C., \& Khan, S. M. (2011). Understanding caregivers' attitudes towards physical punishment of children: evidence from 34 lowand middle-income countries. Child Abuse \& Neglect, 35(12), 1009-1021. 
Chavis, A., Hudnut-Beumler, J., Webb, M. W., Neely, J. A., Bickman, L., Dietrich, M. S., \& Scholer, S. J. (2013). A brief intervention affects parents' attitudes toward using less physical punishment. Child Abuse \& Neglect, 37(12), 1192-1201.

Crosson- Tower, C. (2005). The role of educators in preventing and responding to child abuse and neglect (6. Baskı). U.S. Department of Health and Human Services.

Demir, H. (2013). Edirne ili aile sağlığı merkezlerinde görevli hekimlerin çocuk istismarı ve ihmali hakkında bilgi, farkındalık ve tutumlarının belirlenmesi [The knowledge, awareness and attitude of physicians working in family health centres in Edirne on child abuse and neglect] (Doctoral Dissertation). Trakya University, School of Medicine.

Doğan, N., Soysal, S., ve Karaman, H. (2017). Aynı örnekleme açımlayıcı ve doğrulayıcı faktör analizi uygulanabilir mi? [Can explotary and confirmatory factor analysis be applied to the same sample?]. Pegem Atıf indeksi, 373-400.

Fassler, I. R., Amodeo, M., Griffin, M. L., Clay, C. M., \& Ellis, M. A. (2005). Predicting long-term outcomes for women sexually abused in childhood: Contribution of abuse severity versus family environment. Child Abuse \& Neglect, 29(3), 269284.

Field, A. (2013). Discovering statistics using SPSS (and sex and drugs and rock ' $n$ ' roll). Sage.

General Information About Child Neglect and Abuse. (2018). https://orgm.meb.gov.tr/meb_iys_ dosyalar/2018_04/05104328_1.Yocuk_Yhmal_ve_ YstismarY_HakkYnda_Genel_Bilgi.pdf

Gilbert, R., Widom, C. S., Browne, K., Fergusson, D., Webb, E. \& Janson, S. (2009). Burden and consequences of child maltreatment in highincome countries. The Lancet, 373(9657), 68-81.

Gilgun, J. F. (2003). Protective factors, resilience and child abuse and neglect. http://www.epi.umn. edu/mch/Healthygenerations/hb4b.html

Göbekçin, T. (2013). Çalınan yarınlar: kadınların çocukken uğradığı cinsel istismarı anlamak ve tedavi etmek [Stolen future: understanding and treating women's child sexual abuse]. Paloma.

Griffin, M. L., \& Amodeo, M. (2010). Predicting longterm outcomes for women physically abused in childhood: Contribution of abuse severity versus family environment. Child Abuse \& Neglect, 34(10), 724-733.

Kalaycı, Ş. (2010). SPSS uygulamalı çok değişkenli istatistik teknikleri [SPSS applied multivariate statistical techniques]. BRC.
Kempe, C. H. (1962). The battered child syndrome. Journal of The American Medical Association, $181,17-24$.

Kural- Dıraz, D. (2014). Çocuk istismarı ve inmaline yönelik diş hekimlerinin farkındalık düzeyleri [Dentists' awareness level in regard to child abuse and neglect] (Doctoral Dissertation). Marmara University, Institute of Health Sciences.

Liel, C., Meinck, F., Steinert, J. I., Kindler, H., Lang, K., \& Eickhorst, A. (2019). Is the Brief Child Abuse Potential Inventory (BCAPI) a valid measure of child abuse potential among mothers and fathers of young children in Germany? Child Abuse \& Neglect, 88, 432-444.

Liu, Y., \& Merritt, D. H. (2018). Familial financial stress and child internalizing behaviors: The roles of caregivers' maltreating behaviors and social services. Child Abuse \& Neglect, 86, 324-335.

Maguire-Jack, K., ve Negash, T. (2016). Parenting stress and child maltreatment: The buffering effect of neighborhood social service availability and accessibility. Children and Youth Services Review, 60, 27-33.

Miragoli, S., Camisasca, E., \& Blasio, P. D. I. (2015). Validation of the Child Abuse Potential Inventory in Italy. SAGE Open, 5(3).

Osan, F. (2009). Çalısan çocukların istismarı: mobilya işkolu örneği [Exploitation of working children: Example of furniture sectors] (Master Thesis). Hacettepe University, Institute of Social Sciences.

Ovayolu, N., Uçan, Ö. \& Serindağ, S. (2007). Çocuklarda cinsel istismar ve etkileri [Sexual abuse in child and its effects]. Fırat Sağlık Hizmetleri Dergisi, 2(4), 13-22.

Özer, G. (2014). Ebeveynlerin çocuk cinsel istismarına dair bilinçleri, endişeleri ve aldıkları önlemler [Parents' levels of consciousness, concerns and precautions against child sexual abuse] (Master Thesis). İstanbul University, Institute of Forensic Sciences and Legal Medicine.

Pelendecioğlu, B. \& Bulut, S. (2009). Physical abuse in the family settings. [Çocuğa yönelik aile içi fiziksel istismar.] Abant Izzet Baysal University Journal of Faculty of Education, 9(1), 49-62.

Pett, M. A., Lackey, N. R., \& Sullivan, J. J. (2003). Making sense of factor analysis: The use of factor analysis for instrument development in health care research. Sage Publication.

Polat, O. (2007). Tüm boyutlarıyla çocuk istismarı [Child abuse in all dimensions]. Seçkin. 


\section{iejee}

Rennie, K. M. (1997). Exploratory and Confirmatory Rotation Strategies in Exploratory Factor Analysis. Paper presented at the annual meeting of the Southwest Educational Research Association, Austin, January 24, 1997.

Salzinger, S., Feldman, R. S. \& Hammer, M. (1991). The effect of physical abuse on children's abuse and the personal consequences for the victims. Criminal Justice and Behavior, 18(1) 64-81.

Sarı, i. (2010). Emniyet örgütünde görevli annebabaların fiziksel istismar potansiyellerinin belirlenmesi ve istismarla ilgili aile eğitim programının etkililiği [Determining the child physical abuse potential in mothers and fathers who work at the Turkish national police and the effectiveness of family education program on exploitation] (Doctoral Dissertation). Gazi University, Institute of Educational Sciences.

Sarıbaș, K. A. (2013). Okul öncesi öğretmenlerinin çocuk istismarına yönelik farkındalıklarının belirlenmesi [Determination of pre-school teachers awareness for child abuse] (Master Thesis). Çanakkale Onsekiz Mart University, Institute of Educational Sciences.

Şencan, H. (2005). Sosyal ve davranışsal ölçümlerde güvenilirlik ve geçerlilik [Reliability and validity in social and behavioral measurements]. Seçkin Yayınclik.

Tavşancıl, E. (2014). Tutumların ölçülmesi ve spss ile veri analizi [Measuring attitudes and data analysis with SPSS]. Nobel.

Tezbaşaran, A. (1996). Likert tipi ölçek geliştirme kılavuzu [Likert type scale developmet guide]. Türk Psikologlar Derneği Yayınları.

Topçu, S. (2009). Silinmeyen izler [Indelible marks]. Phoenix.

UNICEF. (2010). Türkiye'de çocuk istismarı ve aile içi şiddet araştırması [Research of child abuse and family violence in Turkey]

UNICEF. (2015). Unicef Annual Report 2014: Our Story. UNICEF.

Uncu, F. (2013). Elazığ ilinde görev yapan sağlık çalışanlarının çocuk ihmal ve istismarı konusunda farkındalık düzeyleri ve bu durumu etkileyen faktörler [Health care workers who work in the province of Elazig levels of awareness about child abuse and neglect, and the factors affecting this situation] (Doctoral Dissertation). Firat University, Institute of Health Sciences.
Uslu, R. I.., Kapçı, E. G., Yıldırım, R. \& Öney, A. E. (2010). Sociodemographic characteristics of Turkish parents in relation to their recognition of emotional maltreatment. Child Abuse and Neglect, 34, 345-353.

Veneziano, L., \& Hooper, J. (1997). A method of quantifying content validity of health related questionnaires. American Journal of Health Behavior, 21, 67-70.

Warren, E. J., \& Font, S. A. (2015). Housing insecurity, maternal stress, and child maltreatment: An application of the family stress model. Social Service Review, 89(1), 9-39.

World Health Organization. (1999). Report of the Consultation on Child Abuse Prevention, 29-31 March 1999, WHO.

World Health Organization. (2002). World report on violence and health. WHO.

Yalçıntaş- Sezgin, E. (2018). İstismar ve inmale uğrayan çocuklar ve eğitimleri. Z. Seçer (Ed.), Risk Altındaki Çocuklar ve Eğitimleri [Children abused and neglected and their education], 97-141. Eğiten Kitap. 